
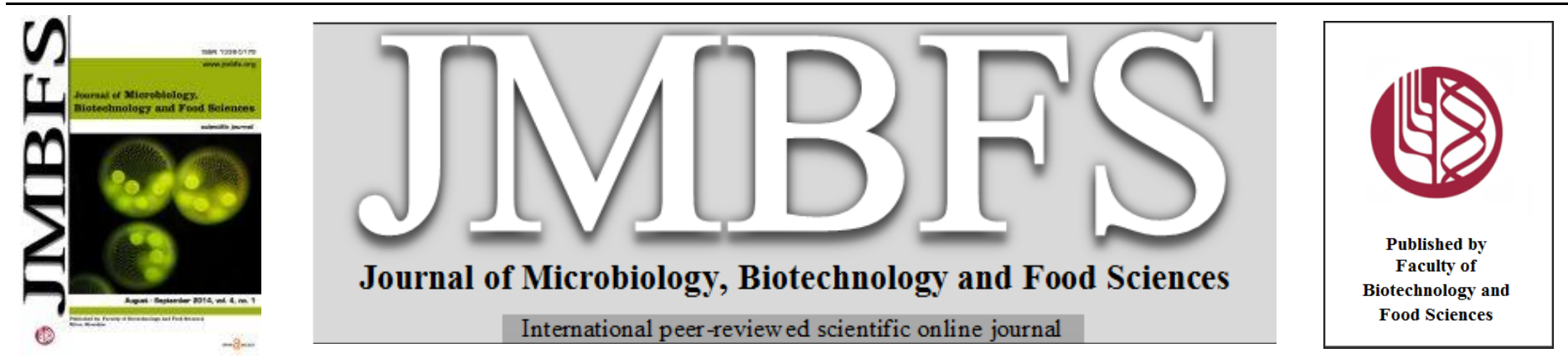

\title{
EXOPOLYSACCHARIDE PRODUCTION BY DROUGHT TOLERANT BACILLUS SPP. AND EFFECT ON SOIL AGGREGATION UNDER DROUGHT STRESS
}

\author{
Sandhya Vardharajula*, Ali Sk Z \\ Address(es): Dr. Sandhya Vardharajula, \\ Department of Microbiology, Agri Biotech Foundation, Acharya N.G. Ranaga Agricultural University, Rajendranagar, Hyderabad-500030, Andhra Pradesh, India.
}

*Corresponding author: sandhyarao28@gmail.com

doi: 10.15414/jmbfs.2014.4.1.51-57

\section{ARTICLE INFO}

Received 14. 10. 2013

Revised 2. 7. 2014

Accepted 10. 7. 2014

Published 1. 8. 2014

Regular article

open $\partial_{\text {access }}$

\begin{abstract}
Exopolysaccharides (EPS) of microbial origin with novel functionality, reproducible physico-chemical properties, are important class of polymeric materials. EPS are believed to protect bacterial cells from dessication, produce biofilms, thus enhancing the cells chances of bacterial colonizing special ecological niches. In rhizosphere, EPS are known to be useful to improve the moisture-holding capacity. Three Bacillus spp. strains identified by 16s rDNA sequence analysis as B. amyloliquefaciens strain HYD-B17; B. licheniformis strain HYTAPB 18; $B$. subtilis strain RMPB44 were studied for the ability to tolerate matric stress and produce EPS under different water potentials. EPS production in all the three Bacillus spp strains increased with increasing water stress indicating correlation between drought stress tolerance and EPS production. Among the isolates, strain HYD-17 showed highest production of EPS. The exopolysaccharide composition of the three strains was further analyzed by HPLC. Drought stress influenced the ratio of sugars in EPS and glucose was found as major sugar in strains HYTAPB18 and RMPB44 whereas raffinose was major sugar found in strain HYDB17. Inoculation of EPS producing Bacillus spp. strains in soil resulted in good soil aggregation under drought stress conditions at different incubation periods. This study shows that exposure to water stress conditions affects the composition and ratios of sugars in EPS produced by Bacillus spp. strains HYD-B17, HYTAPB18 and RMPB44 influencing abiotic stress tolerance of the microorganisms.
\end{abstract}

Keywords: Exopolysaccharide, drought stress, Bacillus spp., soil aggregation

\section{INTRODUCTION}

Dry land areas are stressed environments in terms of water availability and fluctuations in moisture content. Diverse groups of microorganisms associated with these areas are found to produce secondary metabolites such as exopolysaccharides (EPS), which aid in their survival (Decho et al., 1993). Production of EPS as a stress response and survival mechanism under extreme environments has been documented (Nichols et al., 2005). Concentration and composition of microbial EPS dramatically changed under stress conditions (Konnova et al., 2001). Capsular material of A. brasilense Sp245 was found to contain high molecular weight carbohydrate complexes (lipopolysaccharideprotein [LP] complex and polysaccharide-lipid [PL] complex) that could be responsible for protection under extreme conditions, like desiccation. Addition of these complexes to a suspension of decapsulated cells of A. brasilense Sp245, significantly enhanced survival under drought stress (Konnova et al., 2001). Exopolysaccharides are hygroscopic in nature (Morse, 1990) and therefore may maintain higher water content in the colony microenvironment as water potential declines and helps in survival of microorganisms (Roberson and Firestone, 1992). Microorganisms are better suited, since they exhibit high growth rate and are amenable to manipulation of conditions for enhancing growth and EPS production. Bacteria produce wide range of exopolysaccharides (Rehm, 2010). Their components and content heavily depend on many factors, such as bacterial group, cultivation time, substrate and growth state (Read et al., 1987). They are rich in high molecular weight polysaccharides $(10$ to $30 \mathrm{kDa})$ and have wide range of chemical structures of homopolymeric or heteropolymeric type, made up of sugar and non-sugar components, and the range of monosaccharide combinations, together with non-carbohydrate substituents and varied linkage types, makes the EPS an excellent agent and attributes diversity in bacteria (Celik et al., 2008; Kumar et al., 2007). Therefore, bacteria may be regarded as abundant source of structurally diverse polysaccharides with diverse roles in nature, some of which may possess unique properties for special applications such as improvement of water holding capacity of soil, through improved soil aggregations (Asharf et al., 1999; Alami et al., 2000). Despite their ubiquitous distribution, a great lack of knowledge exits concerning the factors that regulate the EPS synthesis. Though, structural elucidation of the polysaccharide is a part of glycomics (Hirabayashi, 2003), their application is important and largely depends on the survival and production of EPS by Bacillus spp. under stress conditions. The acquisition of drought tolerance in Bacillus spp. is associated with various structural and metabolic changes including a decrease in metabolism and in increase in carbohydrates such as exopolysaccharides (Brown, 1990).

EPS from bacteria are complex mixture of high molecular weight polymers forming microbial aggregates that adhere to surfaces and help in cementing soil particles together. In their native state, polysaccharides are easily degraded by other microorganisms but they appear to be protected from such degradation soon after they are firmly bound within an aggregate or incorporated into clay lattice. The exopolysaccharides are attached to clay surfaces by means of cation bridges, hydrogen binding, Van der Waals forces and anion adsorption mechanisms. This, organic products may further promote aggregate stability by reducing wettability and swelling (Hillel, 1982). Stability of soils against erosion and improvement of the soil physical conditions for plant growth are closely related with aggregation. Aggregation is an important part of soil formation because it influences the soil behaviors in infiltration, aeration, root penetration, and reducing runoff. Soil aggregation and water infiltration increases when EPS producing microorganisms are added to crop development. Bashan et al. (2004) reported the role of polysaccharides producing Azospirillum in soil aggregation.

Drought stress limits growth and production of crop plants, particularly in arid and semi-arid areas (Kramer and Boye, 1997). The interaction of drought with other important factors for ecosystem functioning, such as soil aggregation, needs to be studied to gain insight into the impact of drought enhancement. EPS producing bacteria are known to be important for soil aggregation. A key factor in the contribution of Bacillus spp. to soil aggregation is production of EPS under drought stress (Ashraf et al., 1999). Kohler et al. (2006) showed the participation of one of the plant growth promoting rhizobacteria, Pseudomonas mendocina, in both stabilization and promotion of soil fertility. The presence of EPS in soil bacteria has been described primarily in Rhizobium spp. with its primary role in soil aggregation, leading to increased water retention in the rhizosphere (Amellal et al., 1998; Kaci et al., 2005) An EPS producing strain Pseudomonas putida strain GAP-P45 could form biofilm on the root surface of sunflower seedlings and showed improved soil aggregation and root adhering soil stability (Sandhya et al., 2009). The EPS is biological active matrix with 
interesting physico-chemical and rheological properties with novel functionality act as new biomaterials and have wide range of applications. In the recent years, search for novel microbial exopolysaccharides and wide variety of microbia strains are reported to produce polysaccharides with varied compositions and several of these polysaccharides have been investigated to contain interesting and useful properties. (Yalpani, 1987)

The present investigation was aimed to determine correlation between drough tolerance and EPS production and EPS production on soil aggregation by three Bacillus spp. It is also aimed to investigate effect of water stress on monosaccharide composition of EPS.

\section{MATERIAL AND METHODS}

\section{Microorganisms}

Bacillus spp. strains namely, $B$. amyloliquefaciens HYD-B17; $B$. licheniformis HYTAPB18; B. subtilis RMPB44, used in the present study were isolated (Sandhya et al., 2009) from rhizosphere of crop plants grown under different semi arid zones and screened for drought tolerance in Trypticase soya agar (TSA) (pancreatic digest of casein, $17 \mathrm{~g}$; papaic digest of soyabean, $3 \mathrm{~g} ; \mathrm{NaCl}, 5 \mathrm{~g}$; $\mathrm{K}_{2} \mathrm{HPO}_{4}, 2.5 \mathrm{~g}$; dextrose, $2.5 \mathrm{~g}$; Agar, $20 \mathrm{~g}$; per liter) at different water potentials $(-0.05,-0.15,-0.30,-0.49,-0.73 \mathrm{MPa})$ using polyethylene glycol (PEG 6000) The $16 \mathrm{~S}$ rDNA gene sequences of these strains have been submitted to GenBank under the accession numbers GU120097, GQ160905 and GQ160904 respectively. The cultures were maintained on trypticase soy agar under refrigerated conditions.

\section{Growth kinetics under normal and drought stress (-0.73MPa)}

Exponentially grown bacterial culture $\left(10^{9} \mathrm{CFU} \mathrm{ml}{ }^{-1}\right)$ was inoculated in TSB medium without and with PEG6000 (-0.73MPa) and incubated on shaker at $30^{\circ}$ C. Cell population was estimated at $2 \mathrm{~h}$ intervals by plating on respective media and recording optical densities with a spectrophotometer $\left(\mathrm{A}_{600 \mathrm{~nm}}\right)$. The numerical values were $\log$ transformed and plotted against time. Mean generation time calculated according to the formula $\log 10 \mathrm{~N}_{\mathrm{t}}=\log 10 \mathrm{~N}_{0}+\mathrm{g} \log 10^{2}$ where, $\mathrm{N}_{\mathrm{t}} \mathrm{i}$ colony count at final logarithmic growth time; $\mathrm{N}_{0}$ is colony count at initial growth logarithmic time; $g$ is mean generation time. Capsule formation by cultured bacteria was examined by indian ink staining both under non-stress and droughtstress conditions.

\section{Effect of drought stress on EPS production and monomer composition of} EPS

Drought tolerant isolates were analyzed for their ability to produce EPS (Sandhya et al., 2009) under no stress and different stress levels $(-0.05,-0.15$, $0.30,-0.49,-0.73 \mathrm{MPa})$. For extraction of EPS, 3days old cultures raised in TSB (with, and without PEG) were centrifuged at $20,000 \mathrm{~g}$ for $25 \mathrm{~min}$ and the supernatant was collected. This loose layer was collected and resuspended in $0.85 \% \mathrm{KCL}$ and recentrifuged as above to separate capsular material from bacterial cells. The pellet was washed twice with $0.85 \% \mathrm{KCl}$ for complete recovery of EPS. The pooled supernatant was checked for cell disruption by testing the presence of DNA by using DPA reagent (Burton, 1956) and protein concentration by Bradford method (Bradford, 1976). The supernatant was filtered through $0.45 \mu \mathrm{m}$ nitrocellulose membrane and dialysed extensively against water at $4^{\circ} \mathrm{C}$. The dialysate was centrifuged to remove any insoluble material and mixed with 3 volumes of ice-cold absolute alcohol and kept overnight at $4^{0} \mathrm{C}$. The precipitated EPS was collected by centrifugation at $10000 \mathrm{~g}$ for $15 \mathrm{~min}$, suspended in water and further purified by repeating the dialysis and precipitation steps (Sandhya et al., 2009). Total carbohydrate content was determined in the precipitated EPS (Dubois et al., 1956). Uronic acid content was determined also estimated with D-glucuronic acid as the standard (Blumenkrantz and Asboe-Hansen, 1973). The precipitated EPS of the isolates was hydrolyzed with 2 volumes of $2.5 \mathrm{M} \mathrm{H}_{2} \mathrm{SO}_{4}$ at $100^{\circ} \mathrm{C}$ for $1 \mathrm{~h}$, then the solution was neutralized with $1 \mathrm{M}$ sodium carbonate and spotted on the silica gel plate (Silica gel 60F254; Merck). The plate was developed in a thin layer chromatography chamber using n-butanol: acetic acid:water (4:1:5v/v) as the mobile phase at room temperature. The plate was dried, sprayed with alkaline potassium permanganate, and incubated at $100^{\circ} \mathrm{C}$ for $10 \mathrm{~min}$. The $\mathrm{Rf}$ values of colored spots were measured and compared with those of standard carbohydrates (glucose, mannose, fructose, mannitol, arabinose, xylose, rhamnose, raffinose, galactose, and glucuronic acid) (Horborne, 1976).

The monosaccharide composition of exopolysaccharide samples was determined by HPLC (LaChrom HPLC system, Merck, Dietikon, Switzerland) with a refractive index (RI) detector (Bio-Rad, Switzerland), using Aminex HPX-87H ion exclusion column (Bio-Rad, Rheinach, Switzerland) and acetonitrile: milli Q water (75:25) as mobile phase. The organic acids were determined with PDA detector (Bio-Rad, Switzerland) connected following RI detector. Column temperature was maintained at $30^{\circ}$ C. $20 \mu \mathrm{l}$ sample and standards were injected and chromatographed at a constant flow rate of $1 \mathrm{ml} \mathrm{min}^{-1}$ (mobile phase) Monomer analyses of EPS were carried out by Vimta analytical laboratory, R\& D Centre, India.). Peak integrations were carried out with the Millenium HPLC software package (Waters).

\section{Aggregation of soil by EPS producing Bacillus spp.}

Soil used for aggregation studies was collected from homogeneous horizon (0-20 $\mathrm{cm}$ ) of Gunegal research farm (GRF), CRIDA, Hyderabad, India, a semiarid region under rain-fed production system. The soil was air-dried and sieved $(<2$ $\mathrm{mm}$ ) before being analyzed for the physico-chemical properties. The soil contained $71 \%$ sand, $3 \%$ silt, and $26 \%$ clay with $1.60 \mathrm{Mg} \mathrm{m}^{-3}$ bulk density, $39.9 \%$ total porosity, and $37.9 \%$ water holding capacity; it had $\mathrm{pH} 7.0$ and electrical conductivity of $0.103 \mathrm{~ms}$. Organic C, total $\mathrm{N}$ and total P content of soil were, $0.62,0.12$, and $0.05 \mathrm{~g} / \mathrm{kg}$, respectively. Soil water content, determined by drying the initially saturated soil at different matric potentials by pressure plate apparatus (Santra Barbara,CA, USA), was $16.5 \%$ (-0.3 MPa).

The EPS producing, Bacillus spp. strains were grown in TSB and centrifuged at $2000 \mathrm{~g}$ for $10 \mathrm{mins}$ and the pellet obtained was washed with saline $(0.85 \% \mathrm{Nacl})$ twice to remove media components. Pellet was suspended in sterile distilled water $\left(10^{9} \mathrm{cells} \mathrm{ml}^{-1}\right) .100 \mathrm{~g}$ soil sample was transferred into conical flask, sterilized and inoculated with different volumes of bacterial suspension $(0,2 \mathrm{ml}$, $4 \mathrm{ml}, 6 \mathrm{ml}, 8 \mathrm{ml}$ and $10 \mathrm{ml}$ ) maintaining six replicates. In control, flasks with soil samples were treated with sterile distilled water. The inoculated soil samples were incubated for 1 week at $30^{\circ} \mathrm{C}$. During incubation period, soil samples were kept under near the field capacity for non-stress and $40 \%$ (6.5\% of field capacity) water holding capacity for drought stress conditions respectively.

At the end of the incubation period, aggregate stability percentage of the samples was determined using wet sieving method (Bartoli et al., 1991). EPS was extracted from soil by heating the samples at $120{ }^{\circ} \mathrm{C}$ with $5 \mathrm{~N} \mathrm{H}_{2} \mathrm{SO}_{4}$ for $30 \mathrm{~min}$ and filtered through glass fiber filter. Samples were further extracted once with boiling water. The extracts were pooled, and the amount of carbohydrates was estimated by the method of Dubois et al. (1956).

\section{Statistical analysis}

The experiment belonging to EPS production and soil aggregation was performed in a completely randomized fashion with three replicates. Each analysis was done on two samples from each replicate. Results of each representative experiment were analyzed by one-way ANOVA. P values less than 0.05 are considered significant.

\section{RESULTS AND DISCUSSION}

\section{Bacillus spp. growth under water stress}

All the three isolates could tolerate matric stress up to -0.73MPa (Figure 1),

\section{图 HYD-B17 圆 HYTAPB18 R RMPB44}

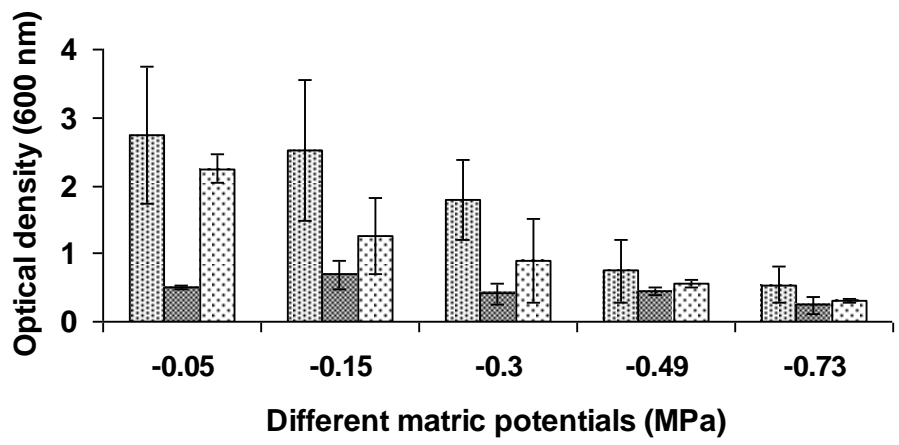

Figure 1 Drought tolerance of Bacillus spp strains under different water potentials. Error bars are mean of \pm standard deviation, $n=6$

however growth pattern of the strains was affected due to matric stress as indicated by lower CFU $\mathrm{ml} 1$ as compared to that under normal conditions (Figure 2). 
a

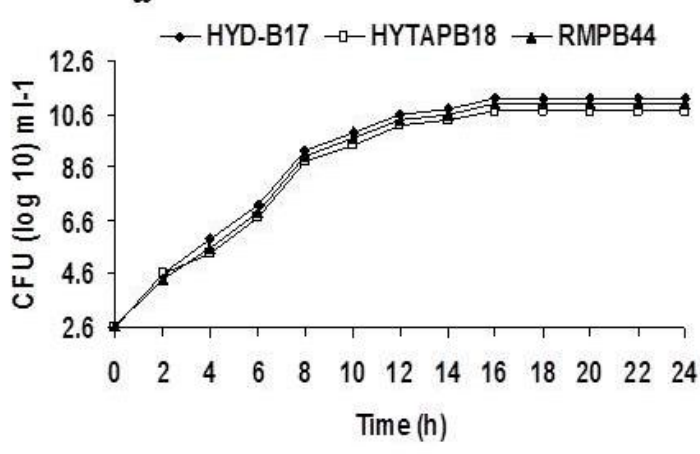

b

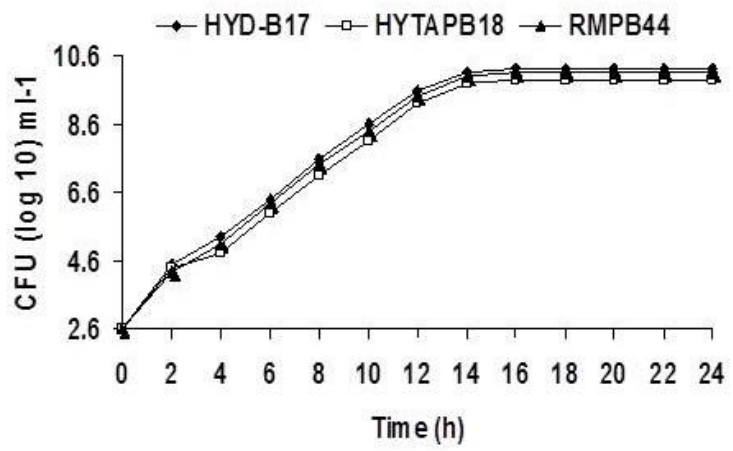

Figure 2 Growth pattern of Bacillus spp. strains under (a), non-stressed and (b), drought-stressed conditions

Mean generation time of the isolates HYD-B17, HYTAPB18, RMPB44 was 36.2 $\mathrm{min}, 38.3 \mathrm{~min}, 37.51 \mathrm{~min}$ respectively under non-stressed conditions and 43.7 min, $46.0 \mathrm{~min}, 44.6 \mathrm{~min}$ respectively under stressed conditions. Strain HYD-B17 could show highest cell population at $-0.73 \mathrm{MPa}$ where as the strain HYTAPB 18 showed highest generation time under drought stress. Bacteria can survive under drought stress conditions due to the production of exopolysaccharide (EPS), which protects microorganisms from water stress by enhancing water retention and by regulating the diffusion of organic carbon sources (Hafsa and Asghari, 2014; Chenu and Roberson, 1996). Strains could tolerate maximum level of matric stress $(-0.73 \mathrm{MPa})$ indicating the presence of stress responsive mechanisms, however growth pattern of the isolates was affected as indicated by increased mean generation time under stress. Under stress conditions energy flow of the cells is directed toward protection mechanisms, which might affect the growth pattern of the cells (Räsänen et al., 2004). The bacterial cells accumulated capsular material under osmotic stress conditions, as indicated by staining with Indian ink. A significant increase in EPS production was observed in all the three isolates with increase in drought stress (from $-0.05 \mathrm{MP}$ to $0.73 \mathrm{MPa}$ ) as compared to non-stressed conditions (Figure 3).

Strain HYD-B17 was the highest EPS producer $\left(324 \mathrm{mg} \mathrm{mg}^{-1}\right.$ protein) followed by strains RMPB44 (298 mg mg ${ }^{-1}$ protein) and strain HYTAPB18 (284 mg mg protein) under maximum level of matric stress (Figure 3). Uronic acid production was also observed under drought stress in all the strains, with strain RMPB44 showing maximum production $\left(26.23 \mu \mathrm{g} \mathrm{ml}^{-1}\right)$ followed by strains HYTAPB18 $\left(21.42 \mu \mathrm{g} \mathrm{ml}^{-1}\right)$ and HYD-B17 $\left(11.65 \mu \mathrm{g} \mathrm{ml} \mathrm{m}^{-1}\right)$. A positive correlation was observed between different levels of matric stress applied and EPS production in all three strains. An increase in the production of EPS with increasing matric stress has been reported in Pseudomonas spp. (Roberson and firestone, 1992). EPS is produced by microorganisms under different environmental stress like drought, salinity, heat, heavy metal stress etc (Afrasayab et al., 2010; Priester et al., 2006; Asharf et al., 1999; Ozturk et al., 2008; Sheng et al., 2006) to form a diffusion barrier between the cell wall and extreme environments (Aquino and Stuckey, 2002). In the present study, drought stress was an important stress factor that might have increased EPS production in Bacillus spp.

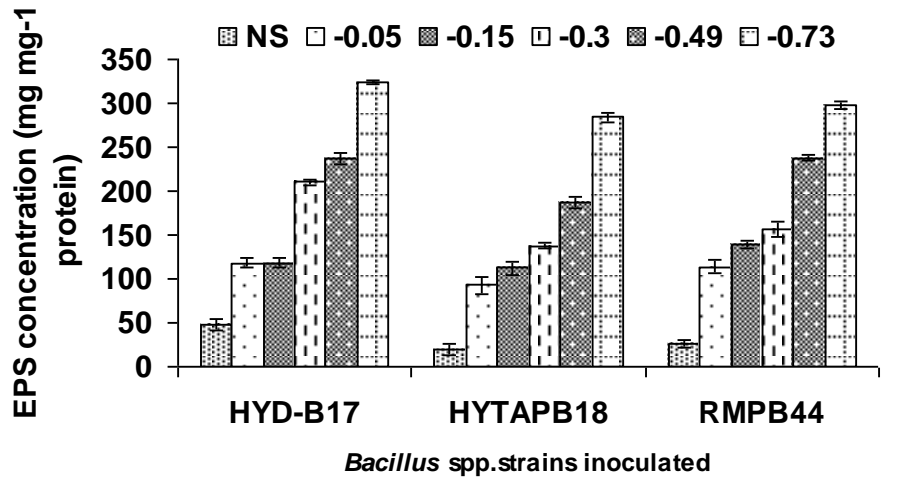

Figure 3 Variability in exopolysaccharide production by Bacillus spp. strains under control and different water potentials. Error bars are mean of \pm standard deviation, $\mathrm{n}=6$

\section{Effect of drought stress on monomer composition of EPS}

EPS produced by the strains with and without PEG6000 (-0.73MPa) was characterized and quantified by HPLC (Table 1; Figure 4).

Table1 Monosaccharide composition expressed as percentage (\%) of the single monosaccharide of the EPS contents of the drought tolerant Bacillus spp.under nonstressed and drought-stressed condition

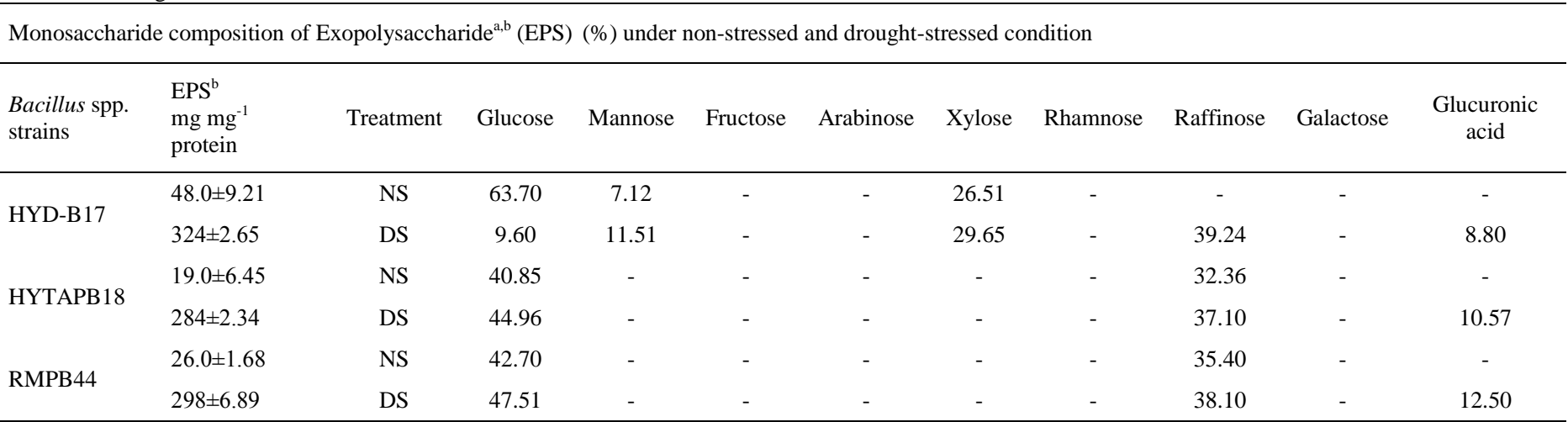

Legend: ${ }^{a}$ Determined by HPLC; ${ }^{b}$ Values represent averages \pm standard deviations for triplicate experiments; - not detected; NS, non-stress; DS, drought-stress 

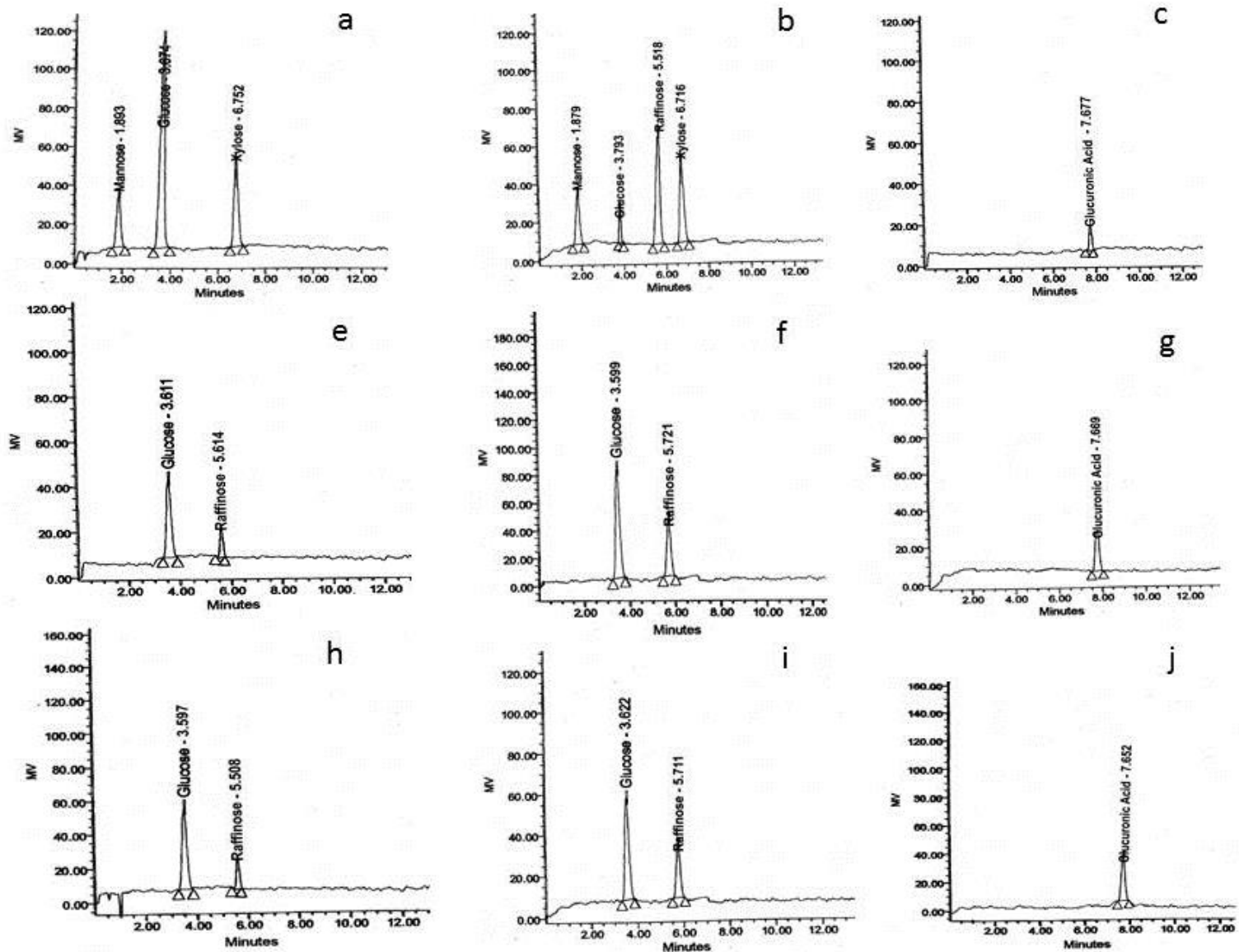

Figure 4 HPLC chromatograms of carbohydrate composition of exopolysaccharide produced by Bacillus spp. strains under non-stress and drought-stressed condition. (a), HYD-B17,non-stress; (b,c), HYD-B17, drought-stress; (e), HYTAPB18, non-stress; (f, g), HYTAPB18, drought-stress; (h), RMPB44, non-stress; (i,j), drought-stress

Determination of the monomer composition of the exopolysaccharide is the first step towards understanding its role in drought tolerance. Under drought stress ( $0.73 \mathrm{MPa}$ ) monomer composition and ratios of sugars changed. Drought stress increased the ratio and composition of monosaccharides in the EPS of all the three Bacillus spp. strains compared to non-stress. Glucose was common monosaccharide detected for three Bacillus spp. strains both under non-stress and drought-stress conditions but the ratio of glucose to other monosaccharides decreased in strain HYD-B17 on exposure to drought stress whereas the ratio of other sugars such as mannose and xylose increased under drought stress and an additional sugar raffinose was detected. In case of strains HYTAPB18 and RMPB44 drought stress increased the ratio of glucose and raffinose in the EPS Raffinose was a major sugar in strain HYD-B17 under drought stress and glucose was a major sugar found in the EPS of strains HYTAPB18 and RMPB44 under drought conditions. These sugars are typically found in bacterial EPS (Kenne and Lindberg, 1983). Manca et al. (1996) reported a sulphated heteropolysaccharide, composed exclusively of mannose and glucose in Bacillus thermoantarcticus strain. It is thought that differences in the monosaccharide composition and ratios of EPS may influence abiotic stress tolerance of the microorganisms (Hussain et al., 2014; Ozturk and Aslim, 2010).

In all the three Bacillus spp. strains glucuronic acid in a range of 18 to $36 \%$ was detected in EPS only under drought stress condition, indicating relation between EPS composition and the drought tolerance in Bacillus spp. It is reported that exopolysaccharides produced by marine bacteria generally contain $20-50 \%$ of the polysaccharide as uronic acid (Kennedy and Sutherland, 1987). In a study on bacterium Halomonas isolated from hyper saline habitats contain high uronic acid with acidic carboxyl group that is ionisable at saline $\mathrm{pH}$ conditions, this contributes a negative charge to the overall polymer counteracting negative effect of salt (Bouchotroch et al., 2000; Corsaro et al., 2004).

\section{Bacillus spp. and soil aggregation}

The effects of different population sizes of Bacillus spp. strains HYD-B17, HYTAPB18 and RMPB44 on aggregation stability and EPS concentration under non-stressed and drought-stressed conditions are given in Table 2 respectively.

Table 2 Aggregate stability (AGS) percentages and percent change (PC) in aggregation according to aggregation in control under non-stress and drought-stress conditions with drought tolerant Bacillus spp.

\begin{tabular}{|c|c|c|c|c|c|c|c|c|c|c|}
\hline \multirow[t]{2}{*}{$\begin{array}{l}\text { Inoculation } \\
\text { dose } \mathrm{ml}\end{array}$} & \multirow[b]{2}{*}{ Treatment } & \multicolumn{3}{|c|}{$\begin{array}{c}\text { Strain } \\
\text { HYD-B17 }\end{array}$} & \multicolumn{3}{|c|}{$\begin{array}{c}\text { Strain } \\
\text { HYTAPB18 }\end{array}$} & \multicolumn{3}{|c|}{$\begin{array}{c}\text { Strain } \\
\text { RMPB44 }\end{array}$} \\
\hline & & $\begin{array}{c}\text { EPS } \\
\mu \mathrm{g} \mathrm{g}^{-1} \text { soil }\end{array}$ & $\begin{array}{c}\text { AGS } \\
\%\end{array}$ & $\begin{array}{c}\mathrm{PC} \\
\%\end{array}$ & $\begin{array}{c}\text { EPS } \\
\mu \mathrm{g} \mathrm{g}^{-1} \text { soil }\end{array}$ & $\begin{array}{c}\text { AGS } \\
\%\end{array}$ & $\begin{array}{c}\mathrm{PC} \\
\%\end{array}$ & $\begin{array}{c}\text { EPS } \\
\mu \mathrm{g} \mathrm{g}^{-1} \text { soil }\end{array}$ & $\begin{array}{c}\text { AGS } \\
\%\end{array}$ & $\begin{array}{c}\mathrm{PC} \\
\%\end{array}$ \\
\hline \multirow{2}{*}{ Control } & NS & $1.64 \pm 0.20$ & $41.2 \pm 2.12$ & & $1.64 \pm 0.20$ & $41.2 \pm 2.31$ & & $1.64 \pm 0.20$ & $41.2 \pm 2.46$ & \\
\hline & DS & $1.70 \pm 0.21$ & $43 \pm 2.36$ & & $1.70 \pm 0.21$ & $42 \pm 2.36$ & & $1.70 \pm 0.21$ & $42 \pm 2.02$ & \\
\hline \multirow{2}{*}{2} & NS & $3.73 \pm 0.15$ & $50 \pm 4.27$ & 18.6 & $2.73 \pm 0.28$ & $44 \pm 4.56$ & 4.91 & $3.15 \pm 0.56$ & $46 \pm 6.02$ & 9.1 \\
\hline & DS & $4.45 \pm 0.10$ & $52 \pm 1.02$ & 19.8 & $3.38 \pm 0.17$ & $48 \pm 4.12$ & 12.3 & $3.83 \pm 0.31$ & $50 \pm 1.56$ & 15.9 \\
\hline \multirow{2}{*}{4} & NS & $3.93 \pm 0.18$ & $56 \pm 5.47$ & 32.8 & $3.13 \pm 0.06$ & $52 \pm 2.45$ & 23.9 & $3.54 \pm 0.18$ & $54 \pm 4.01$ & 28.1 \\
\hline & DS & $4.90 \pm 0.13$ & $58 \pm 3.65$ & 33.3 & $3.71 \pm 0.25$ & $53 \pm 2.98$ & 24.1 & $4.11 \pm 0.13$ & $56 \pm 2.37$ & 29.8 \\
\hline \multirow{2}{*}{6} & NS & $4.66 \pm 0.14$ & $60 \pm 2.38$ & 42.3 & $3.53 \pm 0.32$ & $56 \pm 3.15$ & 33.6 & $4.35 \pm 0.07$ & $58 \pm 3.25$ & 37.6 \\
\hline & DS & $5.58 \pm 0.30$ & $63 \pm 5.25$ & 45.3 & $4.73 \pm 0.42$ & $60 \pm 3.45$ & 40.5 & $4.85 \pm 0.09$ & $61 \pm 4.12$ & 41.4 \\
\hline \multirow{2}{*}{8} & NS & $5.23 \pm 0.18$ & $66 \pm 3.68$ & 56.6 & $3.89 \pm 0.37$ & $62 \pm 4.78$ & 47.9 & $4.92 \pm 0.49$ & $64 \pm 4.51$ & 51.8 \\
\hline & DS & $6.29 \pm 0.41$ & $68 \pm 2.15$ & 57.0 & $5.24 \pm 0.33$ & $66 \pm 2.47$ & 54.5 & $5.33 \pm 0.32$ & $67 \pm 5.24$ & 55.3 \\
\hline \multirow{2}{*}{10} & NS & $5.46 \pm 0.85$ & $69 \pm 2.02$ & 63.7 & $4.74 \pm 0.20$ & $65 \pm 2.02$ & 55.1 & $5.23 \pm 0.09$ & $67 \pm 6.32$ & 58.9 \\
\hline & DS & $6.30 \pm 0.35$ & $72 \pm 1.04$ & 66.2 & $5.36 \pm 0.32$ & $68 \pm 1.00$ & 59.2 & $5.65 \pm 0.43$ & $69 \pm 4.56$ & 59.9 \\
\hline
\end{tabular}

Legend: NS, non-stress; DS, drought-stress; EPS, exopolysaccharide; AGS, aggregate stability; PC, percent change. Numerical values are mean \pm SD of six independent values 
Effect of inoculation doses of each Bacillus spp. strains on aggregation and EPS content was higher under drought stressed condition compared to non-stressed condition. A corresponding increase in EPS production and percent aggregate was observed with increase in inoculum dose. However no significant difference was observed between $8 \mathrm{ml}$ and $10 \mathrm{ml}$ dose with respect to percent aggregation except under drought stress samples inoculated with strain HYD-B17 (Table 2). Therefore $8 \mathrm{ml}$ dose was selected for further studies on effect of incubation period on EPS production and percent aggregate. In all the inoculated soi samples HYD-B17 could show higher EPS content and aggregate stability percentage compared to strains HYTAPB18 and RMPB44. The effect of differen incubation periods (I, II, III, IV, V weeks) on aggregation and EPS of the samples inoculated with $8 \mathrm{ml}$ culture dose was studied for all the three strains (Figure 5).
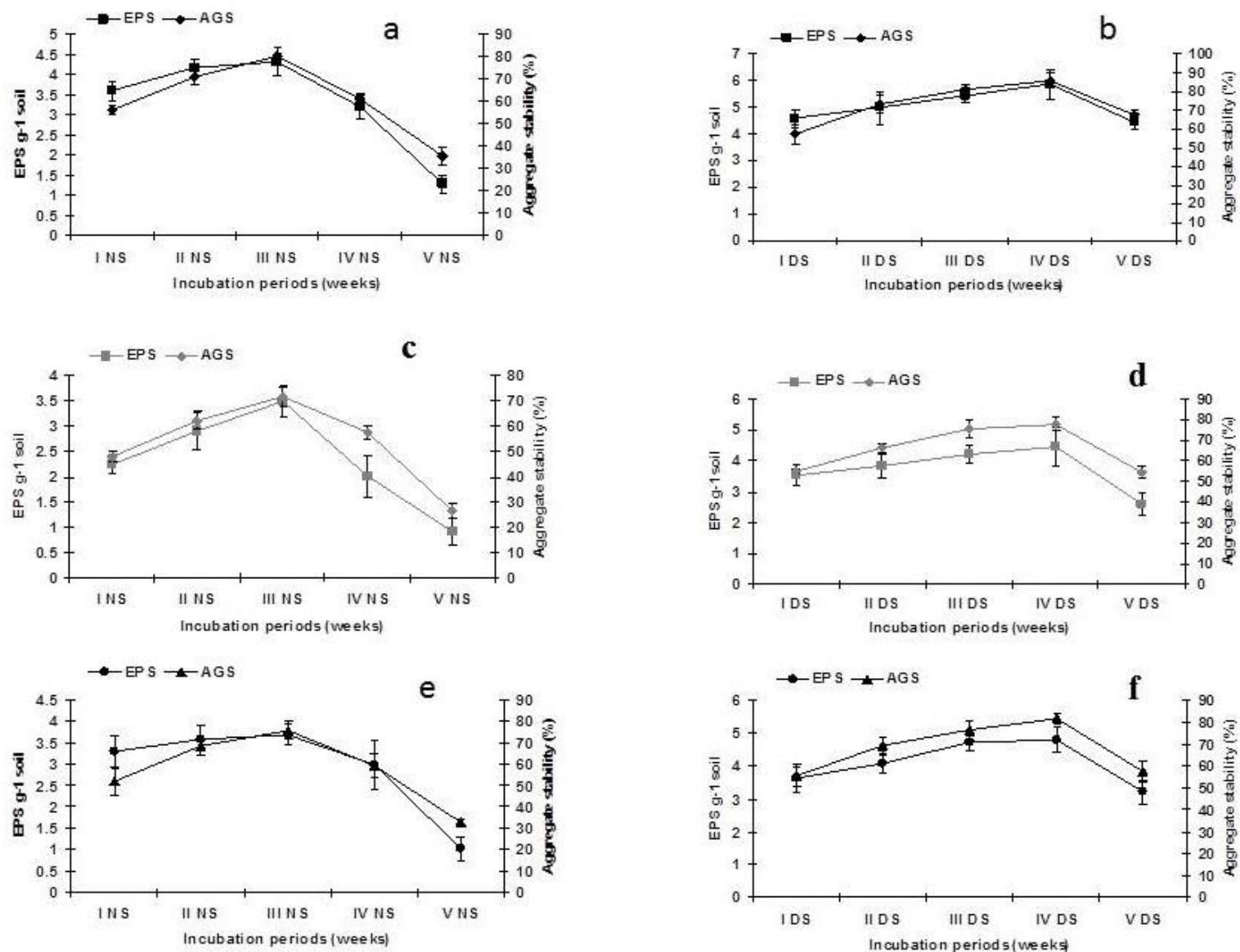

Figure 5 Percent increase in aggregate stability over aggregation in control at different incubation periods inoculated with Bacillus spp. (a, d) Inoculation dose of strain HYD-B17; (b, e) Inoculation dose of strain HYTAPB18; (c, f) Inoculation dose of strain RMPB44.EPS, exopolysaccharide; a, b, c, non-stress; d, e, f, drought-stress. Error bars are mean of \pm standard deviation, $n=6$

A sharp increase in EPS production was observed after one week followed by a steady increase up to three weeks under non-stress and four weeks under droughtstress conditions for all the strains. There after a sharp decline was observed in EPS production. Percent aggregation showed a positive correlation with EPS production for all the treatments. For all the incubation periods EPS produced under stressed conditions was significantly higher than under non-stressed conditions for all the three strains. Microbial exopolysaccharides due to high $\mathrm{C}$ content can be an important factor affecting soil aggregation (Aisha et al., 2014 Roberson et al., 1995). There is strong evidence that exopolysaccharides contribute to soil aggregation stability (Martin, 1971; Bashan et al., 2004). EPS forms an organo-mineral sheath around the cells, which leads to an increase in microaggregates as an indirect additional effect improving the soil structure Microbacterium arborescens have been shown to cement soil particles togethe by forming polysaccharide substances (Aureen, 2009). Forster (1979) has stressed the importance of bacteria in the aggregation of dune sand. Inoculation of EPS producing Rhizobium spp. increased aggregate stability under drough stress (Alami et al., 2000). Increase in aggregate stability was observed with increase in inoculation doses of Bacillus spp. strains HYD-B17, HYTAPB18 and RMPB44 both under no stress and drought stress, however increase was higher under drought stress due to increase in EPS production. Among the three Bacillus spp. strains inoculated, strain HYD-B17 could show higher aggregate stability due to higher production of EPS as reflected by high monomer composition under drought stress conditions. A positive correlation was observed between bacterial population size and EPS production and aggregate stability indicating that a threshold population is required for effective soil aggregation. Further incubation period also play important role in EPS production and soil aggregation. Under non-stress conditions an increase in EPS production and soil aggregation was observed up to three weeks followed by decline whereas under stress conditions an increase in EPS production and soil aggregation was observed up to four weeks. Further amount of EPS produced and soil aggregation was significantly higher under stress conditions than under non-stress conditions at different incubation periods. Under stress conditions bacteria produce more EPS to prevent the cells from matric stress. The excess EPS thus produce also improves soil aggregation under stress conditions. It has been reported that Pseudomonas spp. increases its EPS production with increase in water stress (Roberson and firestone, 1992). The levels of total carbohydrates are higher in soils after drying (Kohler et al., 2009). Organic fraction during soil drying can be used as carbon and energy source by inoculated microorganisms, contributing to the enhancement of microbial activity (Kohler et al., 2009). EPS has the ability to concentrate dissolved nutrients in the bacterial microenvironment during drought stress, which could have been the reason for more bacterial activity resulting in more EPS production that led to increase in aggregation. Aggregation decreased at the end of fifth weeks, it may be explained that due to decrease in substrate material in the soil, affected the bacteria activity and decreasing the production of binding agent (EPS) and also due to consumption of binding agent with increasing incubation period (Waksman, 1952).

\section{CONCLUSION}

This study suggests the fact that EPS molecules are involved in ecological roles by channeling energy and nutrients for growth and protecting the Bacillus spp. cells against water limited environments and contributing to the improvement of soil structure as shown by highest aggregate stability in relation with increase in EPS production by Bacillus spp. under drought stress. Thus inoculations with Bacillus spp. may be useful in restoration of soil structure.

Acknowledgments: The authors are grateful to Indian Council of Agricultural Research (ICAR), New Delhi for providing the financial assistance in the form of network project on Application of Microorganisms in Agriculture and Allied Sectors (AMAAS). 


\section{REFERENCES}

AFRASAYAB, S. FAISAL, M. HASNAIN, S. 2010. Comparative study of wild and transformed salt tolerant bacterial strains on Triticum aestivum growth under salt stress. Brazilian Journal of Microbiology, 41, 946-955. http://dx.doi.org/10.1590/s1517-83822010000400013

AISHA, W. Q. ANJUM, N. S. 2012. Bacterial exopolysaccharide and biofilm formation stimulate chickpea growth and soil aggregation under salt stress. Brazilian Journal of Microbiology, 43,1183-1191. http://dx.doi.org/10.1590/s1517-83822012000300046

ALAMI, Y. ACHOUAK, W. MAROL, C. HEULIN, T. 2000. Rhizosphere soil aggregation and plant growth promotion of sunflowers by exopolysaccharide producing Rhizobium sp. strain isolated from sunflower roots. Applied Environmental Microbiology, 66, 3393-3398 http://dx.doi.org/10.1128/aem.66.8.3393-3398.2000

AMELLAL, N. BURTIN, G. BARTOLI, F. HEULIN, T .1998. Colonization of wheat roots by an exopolysaccharide-producing Pantoea agglomerans strain and its effect on rhizosphere soil aggregation. Applied Environmental Microbiology, 64, 3740-3747.

ASHRAF, M. BERGE, O. AZAM, F. HEULIN, T. 1999. Bacterial exopolysaccharides and productivity of salt affected sites: 1. Diversity of exopolysaccharide producing bacteria isolated from the rhizosphere of wheat (Triticum aesticum L.) grown in normal and saline Pakistani soils. Pakistan Journal of Biology Science, 2, 201-206. http://dx.doi.org/10.3923/pjbs.1999.201.206

AQUINO, S.F. STUCKEY, D.C. 2002. Characterization of soluble microbial products (SMP) in effluents from anaerobic reactors. Water Science and Technology, 45, 127-132.

AUREEN, L.G. SAROJ, B. 2009. Sand aggregation by exopolysaccharide producing Microbacterium arborescens-AGSB, Current Microbiology, 58, 616 621. http://dx.doi.org/10.1007/s00284-009-9400-4

BARTOLI, F. BURTIN, G. HERBILLON, A.J.1991. Disaggreration and clay dispersion of oxisols: Na resin, a recommended methodology. Geoderma, 49, 301-317. http://dx.doi.org/10.1016/0016-7061(91)90082-5

BASHAN, Y. HOLGUIN, G. de-BASHAN, L.E. 2004. Azospirillum-plant relationships: physiological, molecular, agricultural, and environmental advances. Canadian Journal of Microbiology, 50, 521-577. http://dx.doi.org/10.1139/w04.

BLUMENKRANTZ, N. ASBOE-HANSEN, G.1973. New method for quantitative determination of uronic acids. Analytical Biochemistry, 54, 484-489. http://dx.doi.org/10.1016/0003-2697(73)90377-1

BOUCOTROCH, S. QUESADA, E. IZQIERDO. I, RODROGUEZ, M. BEJAR, V. 2000. Bacterial exopolysaccharides produced by newly discovered bacteria belonging to the genus Halomonas, isolated from hypersline habitats in Morocco Journal of Industrial Microbiololgy and Biotechnology, 24, 338-374.

BRADFORD, M. 1976. A rapid and sensitive method for the quantization of microgram quantities of protein utilizing the principle of protein-dye binding $\begin{array}{llll}\text { Analalytical } & \text { Biochemistry, } & \text { 248-258 }\end{array}$ http://dx.doi.org/10.1006/abio.1976.9999

BROWN, A.D. 1990. Microbial water stress physiology. Principles and perspectives, Wiley, New York.

BURTON, K. 1956. A study of the conditions and mechanisms of the diphenylamine reaction for the colorimetric estimation of deoxyribonucleic acid. Biochemistry Journal, 62, 315-332.

CELIK, G.Y, ASLIM, B. BEYATLI, Y. 2008. Characterization and production of the exopolysaccharide (EPS) from Pseudomonas aeruginosa G1 and Pseudomonas putida G12 strains. Carbohydrate Polymers, 73, 178-182. http://dx.doi.org/10.1016/i.carbpol.2007.11.021

CHENU, C. ROBERSON, E.B. 1996. Diffusion of glucose in microbia extracellular polysaccharide as affected by water potential. Soil Biology and Biochemistry, 28, 877-884. http://dx.doi.org/10.1016/0038-0717(96)00070-3 CORSARO, M,M. LANZETTA, R. PARRILLIi, E. PARRILI, M. TUTINO, M.L. UMMARINO, S. 2004. Influence of growth temperature $\mathrm{n}$ lipid and phosphate contents of surface polysaccharides from the Antarctic bacterium Pseudoalteromonas haloplanktis TAC 125. Journal of Bacteriology, 186, 29-34. http://dx.doi.org/10.1128/jb.186.1.29-34.2004

DECHO, A.W. Lopez, G.R.1993. Exopolymer microenvironments of microbia flora. Limnology and Oceanography, $\quad 38, \quad 1633-1645$. http://dx.doi.org/10.4319/lo.1993.38.8.1633

DUBOIS, M. GILLES, K.A. HAMILTON, J.K. REBERS, P.A. SMITH, F. 1956 Colorimetric methods for determination of sugars of related substances. Analytical Chemistry, 28, 350-356. http://dx.doi.org/10.1021/ac60111a017

FORSTER, S.M. 1979. Microbial aggregation of sand in an embryo dune system. Soil Biology and Biochemistry, 11, 537-543. http://dx.doi.org/10.1016/00380717(79)90014-2

HAFSA, N. ASGHARI B. 2014. Role of plant growth-promoting rhizobacteria and their exopolysaccharides in drought tolerance of maize. Journal of Plant Interactions, 9, 689-701. http://dx.doi.org/10.1080/17429145.2014.902125

HILLEL, D. 1982. Introduction to soil Physics. Academic Press Limited, 24-28 Oval Road, London
HIRABAYASHI, J. 2003. Oligosaccharide microarrys for glycomocs. Trends in Biotechnology, 21, 141-143. http://dx.doi.org/10.1016/s0167-7799(03)00002-7 HORBORNE, J,B. 1976. Phytochemical methods. Chapman and Hall, London, p 33.

HUSSAIN, M.B. ZAHIR, Z.A. ASGHAR H.N. ASGHAR, M. 2014. Can catalase and exopolysaccharides producing rhizobia ameliorate drought stress in wheat? International Journal of Agriculture and Biology, 16, 3-13.

KACI, Y. HEYRAUD, A. BARAKAT, M. HEULIN, T. 2005. Isolation and denitrification of an EPS-producing Rhizobium strain from arid soil (Algeria): characterization of its EPS and the effect of inoculation on wheat rhizosphere soil structure. Research in Microbiology, 156, 522-531. http://dx.doi.org/10.1016/j.resmic.2005.01.012

KENNY, L. LINDBERG, B. 1983. Bacterial Polysaccharides. In: Aspinall GO (ed) The polysaccharides. Academic Press, New York, pp 287-363

KENNEDY, A.F.D, SUTHERLAND, I.W. 1987. Analysis of bacterial exopolysaccharides. Biotechnology Applied Biochemistry, 9,12-19.

KOHLER, J. CARAVACA， F. CARRASCO, L. ROLDÁN, A. 2006 Contribution of Pseudomonas mendocina and Glomus intraradices to aggregate stabilization and promotion of biological fertility in rhizosphere soil of lettuce plants under field conditions. Soil Use Management, 22, 298-304. http://dx.doi.org/10.1111/j.1475-2743.2006.00041.x

KOHLER, J. FUENSANTA, C. ROLDÁN, A. 2009. Effect of drought on the stability of Rhizosphere soil aggregates of Lactuca Sativa grown in a degraded soil inoculated with PGPR and AM fungi. Applied Soil Ecology, 42,160-165. http://dx.doi.org/10.1016/j.apsoil.2009.03.007

KONNOVA, S.A. BRYKOVA, O.S. SACHKOVA, O.A. EGORENKOVA, I.V. IGNATOV, V.V. 2001. Protective role of the polysaccharide containing capsular components of Azospirillum brasilense. Microbiology, (Moscow, Russ. Ed.), 70 436-440. http://dx.doi.org/10.1023/a:1010434227671

KRAMER, P.J. BOYER, J.S. 1997. Water relations of plants and soils. Academic Press, San Diego

KUMAR, A.S. MODY, K. JHA, B. 2007. Bacterial exopolysaccharides - a perception. Jounal of Basic Microbiology, 47, 103-117. http://dx.doi.org/10.1002/jobm.200610203

MANCA, M.C.LAMA, L. IMPROTA, R. ESPOSITO, E. GAMBACORTA, A NICOLAUS, B. 1996. Chemical composition of two exopolysaccharides from Bacillus thermoantarcticus. Applied Environmental Microbiology, 62, 3265 3269.

MARTIN, J.P. 1971. Decomposition and binding action of polysaccharides in soil. Soil Biology and Biochemistry, 3, 33-41. http://dx.doi.org/10.1016/0038 0717(71)90029-0

MORSE, S.R. 1990. Water balance in Hemizonia luzulifolia: the role of extracellular polysaccharides. Plant Cell and Environment, 13, 39-48. http://dx.doi.org/10.1111/j.1365-3040.1990.tb01297.x

NICHOLS, C.M. GUEZENNEC, J. Bowman, J.P. 2005. Bacterial exopolysaccharides from extreme marine environments with specia consideration of the Southern Ocean, Sea Ice, and Deep-Sea hydrothermal vents: a review. Marine Biotechnology, 7, pp 253-271. http://dx.doi.org/10.1007/s10126-004-5118-2

OZTURK, S. ASLIM, B. 2010. Modification of exopolysaccharide composition and production by three cyanobacterial isolates under salt stress. Environmental Science Pollution Research, 17, 595-602. http://dx.doi.org/10.1007/s11356-009. $0233-2$

OZTURK. S, ASLIM, B. UGUR, A. 2008. Chromium (VI) resistance and extracellular polysaccharide (EPS) synthesis by Pseudomonas, Stenotrophomonas and Methylobacterium strains. Iron and Steel Institute of $\begin{array}{lll}\text { Japan } & \text { International, } & \text { 1654-1658. }\end{array}$ http://dx.doi.org/10.2355/isijinternational.48.1654

PRIESTER, J.H. OLSON, S.G. WEBB, S.M. NEU, M.P. HERSMAN, L.E HOLDEN, P.A. 2006. Enhanced exopolymer production and chromium stabilization in Pseudomonas putida unsaturated biofilms. Applied Environmental Microbiology, 72, 1988-1996. $\quad$ http://dx.doi.org/10.1128/aem.72.3.19881996.2006

RÄSÄNEN, L.A. SAIJETS, S. JOKINEN, LINDSTRÖM, K. 2004. Evaluation of the roles of two compatible solutes, glycine betaine and trehalose, for the Acacia senegal-Sinorhizobium symbiosis exposed to drought stress. Plant and Soil, 260, 237-251. http://dx.doi.org/10.1023/b:plso.0000030181.03575.e1

REHM, B.H.A. 2010. Bacterial polymers: biosynthesis, modifications and applications. $\quad$ Nature Reviews Microbiology, $\quad 8, \quad 578-592$. http://dx.doi.org/10.1038/nrmicro2354

READ, R.R. COSTERTON, J.W. 1987. Purification and characterization of adhesive exopolysaccharides from Pseudomonas putida and Pseudomonas fuorescens. Canadian Journal of Microbiology, 33, 1080-1090. http://dx.doi.org/10.1139/m87-189

ROBERSON, E.B. FIRESTONE, M.K. 1992. Relationship between desiccation and exopolysaccharide production in soil Pseudomonas sp. Applied Environmental Microbiology, 58, 1284-1291.

ROBERSON, E.B. SARIG, S. SHENNAN, C. FIRESTONE. M.K. 1995. Nutritional management of microbial polysaccharide production and aggregation 
in an agricultural soil. Soil Science Society of America Journal, 59, 1587-1594. http://dx.doi.org/10.2136/sssaj1995.03615995005900060012x

SANDHYA, V. ALI, S.K.Z. MINAKSHI, G. GOPAL, REDDY.

VENKATESWARLU, B.2009. Alleviation of drought stress effects in sunflower seedlings by the exopolysaccharides producing Pseudomonas putida strain GAPP45. Biology and Fertility of Soils, 46,17-26. http://dx.doi.org/10.1007/s00374009-0401-Z

SHENG, G.P. YU, H.Q. YUE, Z. 2006. Factors influencing the production of extracellular polymeric substances by Rhodopseudomonas acidophila International Biodeterioration and Biodegradation, 58, 89-93. http://dx.doi.org/10.1016/j.ibiod.2006.07.005

WAKSMAN, S.A. 1952. Soil microbiology. John Wiley \& Sons. Inc., New York

YALPANI, M. SANDFORD, P.A. 1987. Commercial polysaccharides: recent trends and developments, In: Yalpani M, editor. Industrial polysaccharides: genetic engineering, structure/property relations and applications. Amsterdam: Elsevier Science Publishers, p. 311-35. 